\title{
THE USE OF STUDENT EVALUATIONS TO IMPROVE THE QUALITY OF TEACHING PERFORMANCE
}

\author{
Mara Deković Kesovija, BA \\ American College of Management and Technology, \\ Dubrovnik (Croatia) \\ e-mail: $\underline{\operatorname{marad} @ a c m t . h r}$
}

\begin{abstract}
A b stract
This paper aims to show student evaluations of teaching performance and methods that can help a teacher analyse the results of evaluation concerning his course. The paper also presents suggestions for teaching quality improvement.

The division is made based on four elements of teaching performance that are rated on most rating forms. Suggestions were collected by interviewing twenty teachers judged excellent in these teaching elements by their students. The interviewed teachers were teaching in the fall quarter, academic year 2010/11 at the American College of Management and Technology in Dubrovnik.
\end{abstract}

improvement

Key words: student evaluations, analysis of results of evaluation, teaching quality

\section{Introduction}

With the reform of higher education and the implementation of the Bologna process, today we consider student evaluations of teaching performance as an integral part of teaching practice in almost all higher education institutions in Croatia. In the United States, informal student evaluations of universities were started in the 1960's by enterprising college students (Cahn, 1986, 37). Since then, their use has spread so that now they are administered in almost all American colleges and universities and are probably the main source of information used for evaluating faculty teaching performance (Cave et al., 1997, 147). This paper aims to show what student evaluations of teaching performance are, methods that can help a teacher to analyse the results of evaluation for his course and presents suggestions for teaching quality improvement. The division is made based on four elements of teaching performance that are rated on most rating forms (setting out course objectives clearly to students, presenting class material at an appropriate pace, methods of testing students' knowledge and developing and enhancing students' critical thinking skills). Suggestions were collected by interviewing twenty teachers judged excellent in these teaching elements by their students. The interviewed teachers were teaching in the fall quarter, academic year 2010/11 at the American College of Management and Technology in Dubrovnik, study programs: Information Technology and Service Management. 


\section{Student evaluations of teaching performance}

Although there are numerous methods for testing the quality of the educational process, a teacher's teaching performance and course itself (such as teacher self-evaluation, evaluation by peers, by expert judges and etc.), student evaluations of teacher's teaching performance represent one of the most commonly used methods. The goal of student evaluations is to provide complete information to the teacher about how effectively his teaching is contributing to student learning. They are also used to provide information about the overall quality of the courses, for administrative review (salary setting, promotion, etc.), as an evaluation of institution itself, and may help the students in selecting courses. Although the goals of student evaluations are various, one of the most important is the direct feedback to the teacher about his course and teaching practice.

What is evaluated by this method? Surveys used to evaluate are different, but fundamentally they are composed of general and specific questions. They are used in order to get students' feedback about the overall quality of course and teaching performance. Then these elements are broken down into the specific and focused elements of the course organization and content, including teacher qualities, such as: personal characteristics (consistency, motivation, communication skills, objectivity, fairness, etc.), his attitude toward students (respect, cooperation, kindness etc.), and teacher's teaching skills and competences.

\section{Analysis of the results of student evaluations}

Analysis of the results of student evaluations is sometimes a challenge for teachers.

The results of student evaluations that the teacher gets are generally quantitative and qualitative data. Quantitative results are not difficult to interpret, and while reading them the teacher should take into account how the summary ratings for each element correspond to its own educational goals and educational expectations of the department. However, teachers say that it is not easy to analyze the qualitative results (qualitative comments of students with praise and observations on a teacher's work), since they are often rich in contradictory statements. However, questions that require qualitative feedback in evaluations are preferable, since they give a deeper insight into both positive and negative aspects of evaluated element (Harvey, 2001). In literature we find different methods that can help teachers in analyzing the qualitative results. These methods offer ways to translate the qualitative individual feedback in a useful form. The problem stems from the fact that comments that teachers receive are not organized or structured, and teachers often read them starting from top to bottom (Lewis, 1991). Therefore, the author believes that teachers should first impose some structure on these comments. Morrison (1995) describes a method he devised in order to get a visual picture of the pattern of student comments, a 'chart' in order to facilitate the organization of these comments. The teacher can make a list of characteristics he believes are conducive to effective teaching. Then group the students' comments according to the characteristic to which they relate. Teacher should then mark negative comments with the minus sign (-) and positive with the plus sign (+). After that, checkmark each comment next to each category, so that the teacher can see the actual number of the most written comments. 
An example of the analysis of qualitative student comments:

$\begin{array}{lccc}\begin{array}{l}\text { Characteristics of effective } \\ \text { teaching }\end{array} & + & - & \text { Conclusion } \\ \text { Organization of teaching } & \sqrt{ } & \sqrt{ } \sqrt{ } \sqrt{ } \\ \text { materials } & \sqrt{ } & \sqrt{ } \sqrt{ } \\ \text { Clarity of presentation } & \sqrt{ } \sqrt{ } & \sqrt{ } \\ \text { Communication skills } & \sqrt{ } \sqrt{ } \sqrt{ } & \\ \text { Group work } & \sqrt{ } \sqrt{ } \sqrt{ } & \\ \text { Interaction with students } & \end{array}$

Consultants for teaching and learning often use a method of reading through all the comments, and then sort them into two categories where they group together comments that say nearly the same. In this way they get two basic categories, advantages and disadvantages, with lists of comments, where each category begins with the most often written comments. Teachers say that this summary enables them to analyze students' qualitative comments systematically.

After the teacher has analyzed student evaluation results for his course, the teacher should carefully consider all aspects of the teaching process, because effective student evaluations of teaching performance actually do not provide answers to teachers, but questions (Cashin, 1990). The aim of these indicators is to encourage teachers to reflect on their own educational goals and beliefs. Crucial in improving the teacher's teaching is actually reflection on the process of learning and what is psychologically necessary to teach it adequately (Way, 1992). Furthermore, the teacher should observe and reflect on student evaluations that do not coincide with his own assessment. Then the teacher should observe and think about his own learning goals and ask himself whether students met these goals. The teacher may consider his own advantages and disadvantages of teaching that students point out, and analyze what specific teaching behaviours led to the high and lower ratings in these teaching elements. The teacher then should turn to elements of teaching were students mention the need for improvement. It would be desirable that the teacher, for one or two elements of the teaching that students evaluated negatively, determine strategies for improving them, and apply them to the next lecture. It is certainly important that the teacher determines the importance of individual elements of teaching performance, and compares the students' problems with his own verdicts.

\section{Suggestions for improving the quality of teaching performance}

In this section of the paper the aim was to show suggestions of strategies that fellow teachers use in order to improve the quality of teaching performance. Suggestions were collected by interviewing twenty teachers who taught in the fall quarter, academic year 2010/11 at the American College of Management and Technology in Dubrovnik. Interviewed teachers taught courses at two study programs: Information Technology and Service Management. The purpose of the interview was to summarize different strategies of teachers who are judged excellent in those teaching elements by their students. The division 
is made on four elements of teaching performance that are rated on most rating forms, and which require different kinds of skills from the teacher:

- setting out course objectives clearly to students

- presenting class material at an appropriate pace

- methods of testing students' knowledge

- developing and enhancing students' critical thinking skills

If any of these elements has failed to meet the needs of students, it can often lead to overall lower students' ratings of teaching performance for that course.

\section{Setting out course objectives clearly to students}

To set out course objectives of their courses clearly to students, teachers mention the following suggestions, which they use in their teaching practices: course outline;

- at the beginning of the quarter they give and explain to students syllabus and

- at the beginning of each lecture they explain clearly to students how that class session fits into the course as a whole; for classes;

- they give clear and precise instructions on how students are expected to prepare

- at the beginning of each lecture they outline the class session for the students;

- they review their course organization together with a colleague who teaches the related course.

\section{Presenting class material at an appropriate pace}

To present material to students at an appropriate pace teachers:

- begin their lecture by introducing a topic for that class, and they try to focus their lecture around that concept.

- take a 10 minute break after 50 minutes, if the lecture is longer than one hour, and in that way help keep students focused. session.

- try to maintain a limit of maximum 3-5 points of discussion in a single class

- prepare an additional topic for discussion or additional tasks in case they misjudge the time.

- divide their lecture into 10-minute segments.

\section{Methods of testing students' knowledge}

For this element of teaching performance, teachers say that they:

- use methods of testing that measure different skills and abilities of students. 
- use multiple and combined methods of testing (writing essays, solving task or a problem with the use of textbook, etc.).

- try to create assignments that focus on comprehension and application of the material, problem solving and applying existing knowledge to new situations.

- analyze the degree of difficulty of tests and try to incorporate problems that require basic knowledge, in addition to those that require synthesis and a deeper comprehension of the material.

- try to summarize what they observed during grading students' assignments (points which were most understood, common misconceptions).

- use the methods of testing that are directed at different learning styles.

- ask students to write an example of the test that would meet their own learning needs, and grade them on the level of difficulty and quality of their questions.

- give to students different learning opportunity, by having students retake exams in small groups (after completing the exams individually), and give them extra points (extra credit) for a good score on the group exam.

\section{Developing and enhancing students' critical thinking skills}

To enhance the development of critical thinking skills of students, teachers use the following strategies:

- they try to create a classroom environment in which students will not feel embarrassed to make mistakes, and in this way they allow them to discover their own mistakes and learn from them.

- teachers give to the students assignments which require comprehension and application of the material, i.e. offer problems which require the application of learned material.

- they feel that it is preferable to commend the students who are in class trying to think critically and analytically and, reward them in grading as well.

- they require students to verbalize their ideas and thought process. In this way teachers show to students flaws in their reasoning or approach to the problem, or material.

- teachers encourage students to have different opinions, and to question the opinion of teacher and experts in the field.

- they ask students to prepare questions in advance about the class material.

- they give to students assignments that they need to solve outside the classroom, on "field" through their own experiences.

- teachers require students to keep a diary to record their own thoughts, ideas and difficulties in understanding the material.

- in the classroom, teachers create hypothetical situations, to stimulate discussion among students.

- teachers ask students to explore the arguments for two different sides of an issue.

- in class, teachers explore case studies. 
- in the classroom teachers encourage debates among students on the topic of preexisting conflict (or controversy) that exists within the profession that students are studying.

- teachers ask students to present their own comparison of relationships that exist between different thematic units, in order to help them integrate the material and information.

\title{
References
}

CAHN, S. M. (1986), Saints and Scamps: Ethics in Academia, Totowa, NJ: Rowman \& Littlefield, p. 37

CASHIN, W. E. (1990), Student Ratings of Teaching: Recommendations for Use, (In: IDEA Paper, January, no. 28), Center for Faculty Education and Development, Kansas State University

CAVE, M., HANNEY, S., HENKEL, M. I KOGAN, M. (1997), The Use of Performance Indicators in Higher Education: The Challenge of the Quality Movement, London: Jessica Kingsley Publishers, p. 147 England

HARVEY, L. (2001), Student feedback. A report to the Higher Education Funding Council for

MORRISON, T. (1995), Analyzing qualitative responses on student evaluations: An efficient and effective method, Rockingham: Higher Education Research and Development Society of Australasia

LEWIS, K. (1991-1992), Making Sense (and Use) of Written Student Comments, (In: Teaching Excellence 3:8)

WAY, D. G. (1992), Teaching Evaluation Handbook, Cornell University, Ithaca, NY

Metodički obzori 6(2011)1

Stručni rad

UDK: 371.3012:378.633(497.5Dubrovnik)](049.5)

Primljeno: 15. 7. 2010.

\section{PRIMJENA STUDENTSKIH PROCJENA U SVRHU POBOLJŠANJA KVALITETE IZVEDBE NASTAVE}

\author{
Mara Deković Kesovija, prof. \\ Američka visoka škola za management i tehnologiju, \\ Dubrovnik (Hrvatska) \\ e-mail: $\underline{\operatorname{marad} @ \mathrm{acmt} . \mathrm{hr}}$
}

\section{Sažetak}

$\mathrm{U}$ ovom radu se prikazuju studentske procjene vezano uz realizaciju nastave i na koje načine analiza rezultata tih procjena može biti provedena od strane nastavnika za kolegij koji predaje. Prikazani su, također, primjeri iz prakse u svrhu poboljšanja kvalitete izvedbe nastave.

Podjela je učinjena na osnovu četiri elementa izvedbe nastave, koja se najčešće procjenjuju studentskim anketama. Primjeri iz prakse prikupljeni su intervjuiranjem dvadeset kolega nastavnika koje studenti visoko ocjenjuju u ovim elementima izvedbe 
nastave. Intervjuirani nastavnici u jesenskom semestru akademske godine 2010./11. izvodili su nastavu na Američkoj visokoj školi za management i tehnologiju u Dubrovniku.

Ključne riječi: studentske procjene, analiza rezultata procjena, poboljšanje kvalitete izvedbe nastave 